\title{
The Transformation of the Value of Piil Pesenggiri Local Wisdom in Building Harmony Between Natives and Immigrants
}

\author{
Riska Dewi Anggraini ${ }^{1, *}$, Susan Fitriasari ${ }^{2}$ \\ ${ }^{1,2}$ Universitas Pendidikan Indonesia, Bandung, Indonesia \\ ${ }^{*}$ Corresponding author.Email: riskaanggraini@upi.edu
}

\begin{abstract}
The Indonesian nation is a pluralistic nation. These characteristics are manifested in an atmosphere of harmonious community life due to the development of tolerance marked by mutual cooperation, thus forming an identity in a certain tribe. One of them is the philosophy of life that developed in Lampung Province, namely Piil Pesenggiri. This philosophy of life is used by the people of Lampung as a new way of living their daily lives. The research method used is qualitative with an ethnographic approach. It is hoped that the research can describe the value of Piil Pesenggiri's local wisdom in depth and holistically related to inter-ethnic harmony in indigenous and immigrant communities. Data was collected by means of in-depth interviews and participatory observation. The results of the research on the transformation of the value of Piil Pesenggiri's local wisdom in building harmony between natives and immigrants through optimizing traditional leaders, the role of information media, and the role of the government in increasing the existence of Piil Pesenggiri's local wisdom. That way, we will see how the value of Piil Pesenggiri's local wisdom can foster a sense of tolerance and mutual respect between natives and immigrants so that harmony can be created in society.
\end{abstract}

Keywords: Etnic Harmony, Immigrants, Natives, Piil Pesenggiri.

\section{INTRODUCTION}

The swift currents of globalization, as well as the strong modernization that has hit the younger generation have become a challenge for the Indonesian people in preserving the nation's culture. Loss of love for culture can trigger a loss of love for one's own culture. In fact, they idolize foreign cultures compared to their local culture. The phenomenon of the development of the times has resulted in the younger generation experiencing a change in life orientation, so that they are less able to appreciate Indonesian.

Whereas the Indonesian nation is a pluralistic nation. Indonesia has approximately 389 ethnic, cultural, etc. diversity. Each tribe has its own characteristics that serve as an identity. So from this cultural diversity emerged group identity. One of the group identities that characterizes the people of Lampung is Piil Pesenggiri. A principle of life that contains the way of life of the people of Lampung. This principle of life is highly respected and applied in the lives of the Lampung people, especially the Lampung natives.

In applying the principle of life is certainly not easy, many young people consider it old-fashioned and outdated, coupled with the condition of the people of
Lampung province which is very multicultural. The diversity of the Lampung tribal community was caused by the transmigration program launched by the government in the 1969/1970 period and continued until 1974/1975. It is not surprising that Lampung became one of the pioneer areas for transmigration of the inhabitants of the islands of Java and Bali at that time.

The large number of immigrant tribes who inhabit Lampung Province makes it difficult to apply the Piil Pesenggiri value to Lampung natives because the majority of immigrants find it difficult to accept this value. This happens because immigrants have a principle of life in accordance with their culture. Finally, the application of the Piil Pesenggiri value can lead to intertribal conflicts if tolerance and mutual respect are not fostered properly. But in fact almost every city in Lampung Province experienced interethnic conflicts due to the application of the Piil Pesenggiri value by natives to immigrants. The impact of this conflict resulted in a prolonged gap. They underestimate the culture between tribes so that it leads to enmity that is passed down.

However, there is something interesting, based on the mapping conducted by the Political and Regional Development Agency of Lampung Province in 2021, it 
shows that Metro City is one of the cities that does not experience inter-ethnic conflicts. In contrast to other cities, the value of Piil Pesenggiri was very difficult to accept, even causing conflicts. but on the contrary, the people of Metro City are very open and even support each other, live in harmony and side by side and are able to accept the values of Piil Pesenggiri well. Indigenous Lampung in introducing the value of Piil Pesenggiri is done through traditional ceremonies, cultural exhibitions involving interethnicity.

The people of Metro City, both natives and immigrants, really appreciate Piil Pesenggiri. As a small evidence of such intertwined harmony, each tribe helps each other and is enthusiastic in carrying out their respective customs or activities. Gotong royong in maintaining order and environmental security is carried out together, mingling with each other and without being awkward, although in it there are many differences, both differences in language, culture and customs. But it is not a barrier to build inter-tribal harmony. This is what attracts researchers to study the lives of the people of Metro City who are able to openly accept the value of Piil Pesenggiri. Both natives and immigrants maintain harmony with each other.

\section{THEORETICAL REVIEW}

The people of Lampung have the local wisdom of Piil Pesinggiri which means a philosophy of life which consists of self-respect that arises because of the ability to process thoughts and behave maturely both in terms of behavior and actions and be able to coexist and be open with immigrants. Zainal Arifin in his article, "Piil Pesenggiri in principle contains noble values that are dynamic and open to other ethnicities. A life value that is embedded in a person's soul in the form of dignity, selfrespect, and a sense of pride in doing something according to his position and position " [1]. Sulistyowati Irianto and Risma Margaretha in their article, "The core values of Piil Pesenggiri are hospitality (nemui nyimah), big names (juluk adok), ability to mingle with all (nengah nyappor), and mutual cooperation (sakai sambayan). These four elements are a series of lives of the Lampung indigenous people from birth to death rituals, all of which are done to uphold their honor " [2].

Robi Cahyadi Kurniawan in his article, "Piil Pesinggiri's philosophy of life has 4 elements that become pillars that support the survival of the people of Lampung. Piil Pesinggiri is a community guideline to be able to maintain their selfesteem and dignity as an open Lampung community, and uphold togetherness "[3]. So that it can be said that the people of Lampung must have a high sense of concern for other fellow citizens. Lampung society is very pluralist so that friction between tribes is very easy to occur. Some views show pluralism as one of the factors that can cause social conflict, because it departs from an interest, or departs from the cultural supremacy of certain community groups. Many conflicts in Indonesia occur because of such pluralism issues "[4].

Jenny Kurman and Carmel Ronen-Eilon in their article, "Almost all Ethiopian immigrants and $93 \%$ of Florida immigrants find it difficult to adapt to Israeli culture, they think Israel does not welcome their arrival and there are so many differences that result in social inequality which sooner or later will become This conflict occurs because of ignorance among them in recognizing Israeli culture "[5]. The application of the values of piil pesenggiri in indigenous and immigrant communities must uphold openness so that it can be understood easily and does not cause conflict.

\section{METHOD}

In this study, the researchers used a qualitative method, with an ethnographic approach which is expected to describe the phenomenon of inter-ethnic interaction obtained from research participants naturally so that information about the local wisdom of Piil Pesenggiri towards harmony between indigenous and immigrant tribes can be described in depth and holistically. Data was collected by means of in-depth interviews and participatory observation. The researcher chose the Head of National Awareness and Conflict Handling Division. The National Unity and Political Body of Lampung Province, Chair of the Lampung Traditional Balancing Council, Metro City, and Community Leaders. The reason is that it is related to maintaining harmony between communities, they have great authority. The research location is in Metro City, Lampung Province.

Researchers are interested in the research location because first, Metro City has heterogeneous ethnicity, religion, and culture. Second, the population in Metro City is the most diverse compared to other cities. Third, residential areas in Metro are relatively evenly distributed. Fourth, the economic condition of the people in Metro City is relatively balanced. And Fifth, there has never been a conflict between tribes. Data collection techniques are carried out by in-depth interviews and participatory observations.

\section{RESULT AND DISCUSSION}

Metro City is one of the small cities located in Lampung Province. This city consists of 3 major tribes, both the majority and the minority, namely the Javanese, Sundanese and Lampung tribes. The Javanese are the most dominant ethnic group in this city, accounting for $60 \%$ of the total population, while the Sundanese are the second largest ethnic group after the Javanese, which 
account for $30 \%$, while the Lampung ethnic group only accounts for $19 \%$ and the rest are other small ethnic groups. The three of them live side by side and in harmony with all the dynamics of their lives.

Per Engzel and Mathieu Ichou in their article, "the relationship between the immigrant community and the natives reveals the fact that their education level and mindset are different. Migrant communities have the goal of finding a successful life but their existence feels threatened by the natives "[6]. Agnieszka Brzozowska and Agnieszka Postuła in their article, "immigrant communities will experience a cultural clash, they must face these conditions and must adapt to the norms and values prevailing in indigenous areas. Multiculturalism requires openness to accept differences "[7].

Rattan and Ambady in their article, "Multiculturalism can also benefit the majority tribe so that the assimilation process can occur quickly but multiculturalism can also boomerang and cause resistance "[8]. Yogeeswaran \& Dasgupta in their article, "the positive or negative impact of multiculturalism in an area depends on their perspective "[9]. Yara Mahfud, Constantina Badea, Maykel Verkuyten, and Kate Reynolds in their article, "the cause of inter-tribal conflict is misunderstanding between indigenous and immigrant groups "[10].

In fact, the value of Piil Pesenggiri if implemented properly contains the philosophy that a Lampung person must always help others (sakai), so that other people will also help us if they are in (sambayan). This is a transformation of the value of sakai sambayan in its truest sense. In addition, to introduce the value of Piil Pesenggiri widely, it is possible to take advantage of the role of technology and information media such as social media. The target of this socialization is not only teenagers but all groups.

The value of piil pesenggiri is a philosophy that must be preserved. In understanding the four values of piil pesenggiri such as Juluk-adek, it means that every native is obliged to keep the title that has been given and make the best use of the title, Nemui-Nyimah means liking to stay in touch or visiting and generous or like to give. Nengah-nyappur means tolerance among others, upholds a sense of kinship, and Sakai sambaiyan means mutual assistance, solidarity, and mutual cooperation. All the values contained in piil pesenggiri aim to organize life for the better. These values are transformed into social life. Cheryl Klimaszewski Gail E Bader and James M Nyce in their article, "understanding cultural heritage means considering how to interpret values correctly. If it is not interpreted correctly, it will cause problems. "[11].

Ya Hui Michelle See, Aaron Wei Qiang Lim, and Janet V. T. Pauketat in their article, "The role of the government in making certain policies so that the diversity that exists in the region continues to go hand in hand and complement each other. Openness to immigrants is essential for progress "[12]. The local government of Metro City also introduces the value of Piil Pesenggiri through traditional ceremonies, cultural exhibitions involving inter-ethnicity. Not only that, in everyday life, the people of Metro City, such as natives or immigrants, really appreciate Piil Pesenggiri. Piil Pesenggiri becomes the foundation for everyone to progress and develop, but Piil Pesenggiri also makes a person have a high sense of caring for others. This understanding places Piil Pesenggiri not as an individual, but as a social property which will influence the dynamics of the group.

\section{CONCLUSION}

The people of Lampung adhere to the life philosophy of Piil Pesinggiri and have high morals. The philosophy of life as a reference for the people of Lampung to always be open and have a high sense of solidarity. both with fellow groups and with other communities. A multicultural society does not become a barrier in creating harmony between natives and immigrants. They live openly and openly to the value of Piil Pesinggiri.

The transformation of the Piil Pesenggiri value in the people of Metro City has a positive impact on inter-ethnic harmony. Even though the Lampung natives are a minority, the majority ethnic groups such as Javanese and Sundanese openly accept this principle as a cultural heritage. Piil Pesenggiri is actually used to resolve any misunderstandings that occur. This is what causes Metro City to be one of the cities that has an empty record in intertribal conflicts.

\section{REFERENCES}

[1] Z. Arifin, "Piil Pesenggiri: Lampung Community Identity Politics," Patanjala., vol. 12, no. 1, pp. 6985,2020 .

[2] S. Irianto Dan R. Margareth, "Piil Pesenggiri: Cultural Capital and Ulun Lampung Identity Strategy," Makara. Social Humanities., vol. 15, no. 2, pp. 140-150, 2011.

[3] R. C. Kurniawan," Piil Pesenggiri: A Concept of Political Power in Lampung Culture," Jurnal Ilmu Sosial dan Ilmu Politik., vol. 21, no. 1, pp. 74-86, 2017.

[4] Tobroni dan S. Arifin, Islam Cultural and Political Pluralism. Yogyakarta: SI Press, 1994.

[5] J. Kurman and C. R. Eilon, "Lack Of Knowledge Of A Culture's Social Axioms And Adaptation Difficulties Among Immigrants," Journal Of CrossCultural Psychology., vol. 35, no. 2, pp. 192-208, 2004. 
[6] P. Engzell and M. Ichou," Status Loss: The Burden of Positively Selected Immigrants," International Migration Review., vol. xx, no. x, pp. 1-25,2019.

[7] A. Brzozowska and A. Postuła," Feel at Home. Vietnamese Immigrants in Poland," Sage Journal of Space and Culture., vol. 00, no.0, pp. 1-15, 2019.

[8] Rattan and Ambady," Diversity ideologies and intergroup relations: An examination of colorblindness and multiculturalism," European Journal of Social Psychology., vol. 43, no. 0, pp. 12$21,2013$.

[9] Yogeeswaran and Dasgupta, "The devil is in the details: Abstract versus concrete construals of multiculturalism differentially impact intergroup relations," Journal of Personality and Social Psychology., vol.106, no. 0, pp. 772-789, 2014.

[10] Y. Mahfud, C. Badea, M. Verkuyten, and K. Reynolds,"Multiculturalism and Attitudes Toward Immigrants: The Impact of Perceived Cultural Distance," Journal of Cross-Cultural Psychology., vol. 00, no.0, pp. 1-14, 2017.

[11] C. Klimaszewski, G. E. Bader and J. M Nyce," Studying up (and down) the cultural heritage preservation agenda: Observations from Romania," European Journal of Cultural Studies., vol. 15, no. 4, pp. 479-495, 2012.

[12] Y. H. M. See, A. W. Q. Lim, and J. V. T. Pauketat," Values Predict Willingness to Interact With Immigrants: The Role of Cultural Ideology and Multicultural Acquisition,'Journal of Cross-Cultural Psychology., vol. 00, no. 0, pp. 1-22, 2019. 